\title{
DETERMINATION OF LETROZOLE, ANASTROZOLE AND EXEMESTANE BY CAPILLARY ZONE ELECTROPHORESIS
}

\author{
AURA RUSU ${ }^{\mathrm{a}}$, GABRIEL HANCU ${ }^{\mathrm{a}}$, LAVINIA BERTA $^{\mathrm{b}}$, \\ CAMIL EUGEN VARI ${ }^{\mathrm{c}}$
}

\begin{abstract}
A new validated capillary zone electrophoresis method was developed for the quantification of three aromatase inhibitors - anastrozole, letrozole and exemestane. After preliminary analysis a sodium tetraborate background electrolyte containing carboxymethyl $\beta$-cyclodextrine was selected for the simultaneous determination of the three aromatase inhibitors. $100 \mathrm{mM}$ sodium tetraborate containing $5 \mathrm{mM}$ carboxymethyl $\beta$ cyclodextrine as buffer addtive, $25 \mathrm{kV}$ applied voltage, $20 \mathrm{mbar} / 2 \mathrm{~s}$ injection pressure and $25^{\circ} \mathrm{C}$ temperature were selected as optimum parameters for the determination. Analysis was performed in approximately 10 minutes. Validation parameters, including linearity, precision, detection and quantification limits were determined. Our results prove the applicability of capillary zone electrophoresis for the simultaneous determination of the three aromatase inhibitors from pharmaceutical products. The applicability of the optimized method was also tested for biological samples, proving its reliability for the determination of letrozole without any special treatment of the analyzed spiked urine sample and presenting potential for other biological matrices.
\end{abstract}

Keywords: aromatase inhibitors, anastrozole, letrozole, exemestan, capillary zone electrophoresis, cyclodextrines

a University of Medicine and Pharmacy of Targu Mures, Faculty of Pharmacy, Department of Pharmaceutical Chemistry, 38 Gh. Marinescu str., RO-540139, Targu Mures, Romania.

* Corresponding author gabriel.hancu@umftgm.ro

${ }^{b}$ University of Medicine and Pharmacy of Targu Mures, Faculty of Pharmacy, Department of General and Inorganic Chemistry, 38 Gh. Marinescu str., RO-540139, Targu Mures, Romania.

${ }^{c}$ University of Medicine and Pharmacy of Targu Mures, Departement of Pharmacology and Clinical Pharmacy, 38 Gh. Marinescu str., RO-540139, Targu Mures, Romania. 


\section{INTRODUCTION}

Anastrozole (ANA) and letrozole (LET) are nonsteroidal competitive inhibitors of aromatase (Als), the enzyme required for the last step in estrogen synthesis. Exemestane (EXE) is an irreversible aromatase inhibitor with a steroid structure. These drugs are used in the treatment of breast cancer and are administered orally in a daily single dose [1].

ANA is indicated for first-line treatment of postmenopausal women with advanced or metastatic breast cancer, for second-line treatment of postmenopausal patients with advanced breast cancer who have had disease progression following tamoxifen therapy, and for adjuvant treatment of women with early breast cancer. LET is specific for aromatase inhibition, with no additional effects on adrenal corticoid biosynthesis. EXE is a steroid-based aromatase inhibitor approved for the treatment of breast cancer with a mechanism-based inactivator that irreversibly inhibits the enzyme [2]. Although they share a general mechanism of action, the third generation Als produce varying degrees of aromatase inhibition and estrogen suppression [3].

The chemical and physical characteristics of the studied substances are presented in Table 1.

Als are used as off label therapy in male infertility following LH deficiency (in morbid obesity and in anabolic steroid induced hypogonadism) [4-6]. Also, ANA, LET and EXE are included in the Word Anti-Doping Agency Prohibited List [7]; these drugs are used in combination with anabolic steroids to prevent the onset of gynecomastia by estrogenic excess; aromatase inhibitors are also used by doped athletes as post cycle therapy in order to promote restoration of hypothalamic-pituitary-testicular axis integrity $[8,9]$.

Several capillary electrophoretic methods have been reported for determination of Als in combination with other compounds, mainly micellar electrokinetic capillary chromatographic (MEKC) [17-20]. So far, there is no published electrophoretic method for the simultaneous determination of all three Als selected in this research.

The main objective of this study was to elaborate a new simple, rapid and accessible capillary zone electrophoresis (CZE) method for determination of ANA, LET and EXE, with applications in the determination of the studied substances in pharmaceutical products and biological samples. A simple validated CZE method could also be very useful in analysis of Als counterfeit drugs, used by athletes in doping offenses. 
DETERMINATION OF LETROZOLE, ANASTROZOLE AND EXEMESTANE BY ..

Table 1. Chemical structure and physical properties of ANA, LET and EXE.

\begin{tabular}{|c|c|c|c|c|c|c|}
\hline Als & Chemical structure & MW & $\mathrm{p} K_{\mathrm{a}}$ & Solubility & $\begin{array}{l}\log P / \\
\log D\end{array}$ & Ref. \\
\hline ANA & & 293.36 & $\begin{array}{l}p K_{a}=2.01 \\
p K_{a} \text { for }[B H+] \\
=4.78\end{array}$ & $\begin{array}{l}\text { freely soluble in } \\
\text { methanol, acetone, } \\
\text { ethanol, } \\
\text { tetrahydrofuran, } \\
\text { and very soluble in } \\
\text { acetonitrile }\end{array}$ & $\begin{array}{l}\log P \text { P } 0.77 \\
\log D \text { at } \mathrm{pH} \\
7 \text { is } 0.77\end{array}$ & [10-13] \\
\hline LET & & 285.30 & \begin{tabular}{|l|}
$\mathrm{p} K_{\mathrm{a}}$ for $[\mathrm{BH}+]$ \\
$=3.63$ \\
$\mathrm{p} K_{\mathrm{a}}=5.4$ \\
(dibenzonitrile \\
group) \\
$\mathrm{p} K_{\mathrm{a}}$ for $[\mathrm{BH}+]$ \\
$=4.4$ (nitrogen \\
protons in the \\
triazole ring)
\end{tabular} & $\begin{array}{l}\text { freely soluble in } \\
\text { dichloromethane; } \\
\text { slightly soluble in } \\
\text { ethanol; practically } \\
\text { insoluble in water }\end{array}$ & $\begin{array}{l}\log P 1.52 \\
\log D \text { at } p H \\
7 \text { is } 1.52\end{array}$ & [13-15] \\
\hline EXE & 4 & 296.41 & & $\begin{array}{l}\text { freely soluble in } \\
\text { dimethylformamide; } \\
\text { soluble in methanol } \\
\text { and ethanol; sparingly } \\
\text { soluble in acetonitrile; } \\
\text { practically insoluble } \\
\text { in water }\end{array}$ & \begin{tabular}{|l|}
$\log P 3.30$ \\
$\log D$ at pH \\
7 is 03.30
\end{tabular} & {$[13,14,16]$} \\
\hline
\end{tabular}

\section{RESULTS AND DISCUSSION}

Preliminary experiments. At the beginning of determinations we have selected the type of background electrolyte (BGE) by checking the electrophoretic behavior of the analytes using an acidic BGE - phosphoric acid $25 \mathrm{mM}$ and a basic BGE - $25 \mathrm{mM}$ borax. After our prelimary results we selected a $25 \mathrm{mM}$ borax ( $\mathrm{pH}$ 9.3) as BGE also taking in consideration previous electrophoretic studies [17-21].

Method optimization. Electrophoretic behavior of the selected Als are obvious consequences of their physico-chemical properties. In order to obtain a better resolution of the separation various buffer additives as organic solvents, surfactants, $\beta$-cyclodextrines ( $\beta$-CDs) were tested. 
Organic solvents are used in CZE in order to increase solubility of the analytes [20,22]. Addition of organic solvents (methanol, acetonitrile, npropanol, dimethylformamide) could not improve the resolution, probably because the selected Als exhibit very close electrophoretic mobility's that cannot be differentiated by adding a small amount of organic solvent. Moreover, addition of organic solvents increased migration times.

We tried to improve separation by using the most commonly used surfactant, sodium dodecylsulfate (SDS) $(20-100 \mathrm{mM})$, an anionic surfactant, in varying concentrations of BGE $(25-100 \mathrm{mM})$. Although ANA, LET and EXE are in neutral form in this BGE all three compounds migrated with the same electrophoretic mobility [24].

Because of similarity of chemical structures between ANA and LET we choose to add in BGE a variety of $\beta$-cyclodextrines $(\beta-C D)$ derivatives in order to improve the separation resolution: $\beta$-cyclodextrine (MW 1135, native CD), 2-hydroxypropyl $\beta$-cyclodextrine (2-HP- $\beta$-CD) (MW 1460, neutral derivatized $C D$ ), carboxymethyl $\beta$-cyclodextrine $(C M-\beta-C D)$ (MW 1541, anionic $C D$ ), and sulfobutyl $\beta$-cyclodextrine (SB- $\beta-C D$ ) (MW 2245, anionic $C D$ ). Usually, $C D s$ are the most popular chiral selectors used in capillary electrophoresis (CE) or for increasing aqueous solubility, higher dissolution rate and intestinal permeation of drugs [22, 24]. Adding $\beta-C D$ derivatives to BGE $(5-15 \mathrm{mM})$ improved the separation of ANA, LET and EXE. Also, we used dual CD systems ( $\beta-C D$ and $C M-\beta-C D$ in various concentrations between $5-15 \mathrm{mM}$ ) containing a neutral $C D$ and a ionized one, and studied their influence on the separation. Due to encouraging results obtained by using $\beta-C D$ derivatives as BGE additives we tried to combine $\beta-C D$ derivatives with small concentration of SDS, without improving the analytes separation.

The influence of the most important electrophoretic parameters (BGE concentration and $\mathrm{pH}$, applied voltage, temperature, injection time and pressure) on the separation was studied and the parameters were optimized.

The migration times of the analytes increased with the increase of the BGE concentration, because of the decrease of electroosmotic flow (EOF) with the increase in ionic strength.

In CZE the pH of BGE is very important since affects ionization of the analytes and their electrophoretic mobility. Using MarvinSketch 17.1.2 (ChemAxxon) chemical editor [25] we found that major microspecies of selected Als are neutral in the range of $\mathrm{pH} 4-13$.

We varied the $\mathrm{pH}$ of BGE between $8.30-10.40$ by adding small amounts of $1 \mathrm{M} \mathrm{NaOH}$ and $1 \mathrm{M}$ boric acid without satisfactory results (no improvement of separation under 9.4 values and at $\mathrm{pH}$ values greater than 9.4 the migration time are longer and peaks are distorted). 
Regarding the influence of applied voltage and system temperature, the migration times decreased with the increase of these parameters, the limiting factors being the Joule heating and the viscosity of BGE which is directly related with temperature. We selected an applied voltage of $25 \mathrm{kV}$ and a temperature of $25^{\circ} \mathrm{C}$ as optimum parameters.

The migration times were slightly influenced by injection pressure and time; however, injection parameters influenced peak shape and amplitude. Thus, a $20 \mathrm{mbar}$ injection pressure and a short injection time (2 seconds) were chosen to avoid peak broadening or splitting.

Thereby, ANA, LET and EXE can be separated with the optimized parameters within 10 minutes (Figure 1). The best separation was obtained using a $100 \mathrm{mM}$ sodium tetraborate containing $5 \mathrm{mM} C M-\beta-C D, 25 \mathrm{kV}$ applied voltage, $20 \mathrm{mbar} / 2 \mathrm{~s}$ injection pressure and $25^{\circ} \mathrm{C}$ temperature as optimum parameters (Table 2). The confirmation of peaks identity was achieved by comparing migration times of individual analytes and overlaying the UV spectra using the electrophoretic system photodiode detector with the ones obtained from standards.

Table 2. Parameters of ANA, LET and EXE separation by CZE (T - migration time, A - area, H - height, Symm. - symmetry, Res. - resolution, Sel. - selectivity).

\begin{tabular}{|c|c|c|c|c|c|c|c|c|}
\hline Als & $\begin{array}{c}\text { T } \\
(\mathrm{min})\end{array}$ & $\begin{array}{c}\text { A } \\
(\mathrm{mAU} \mathbf{s})\end{array}$ & $\begin{array}{c}\text { H } \\
(\mathrm{mAU})\end{array}$ & Symm. & $\begin{array}{c}\text { Width } \\
(\mathrm{min})\end{array}$ & Plates & Res. & Sel. \\
\hline ANA & 4.871 & 10.32 & 2.20 & 0.80 & 0.085 & 17841 & - & - \\
\hline LET & 6.040 & 25.10 & 6.22 & 0.17 & 0.034 & 168966 & 11.4 & 1.24 \\
\hline EXE & 8.506 & 7.03 & 1.96 & 0.32 & 0.037 & 291505 & 40.44 & 1.41 \\
\hline
\end{tabular}

It is known that the electrophoretic mobility is related to charge and mass $\left(\mu_{\mathrm{pH}} \mathrm{vs} . \mathrm{q} / \mathrm{M}^{\alpha}\right)$. Semiempirical methods describe this relation which differ in the a value which is $1 / 3$ in the Stoke's law, and $2 / 3$ in Offord's approach [26]. Molar mass values of the three compounds are very close (Table 1). A notable difference we distinguish on EXE chemical structure which is a steroidal neutral compound. There are published studies related to the complexation of EXE with $\beta-C D$ derivatives in terms of increased aqueous solubility of drug, higher dissolution rate and intestinal permeation [27-29]. Thereby is very probable that EXE could form a complex more soluble with $C M-\beta-C D$ from the $B G E$ and that may explain the longest migration time. Although ANA and LET are compounds of high structural similarity, differences also exist in their molecular shape and association capability with CM- $\beta-C D$ [30]. These properties also influence the electrophoretic mobility. 


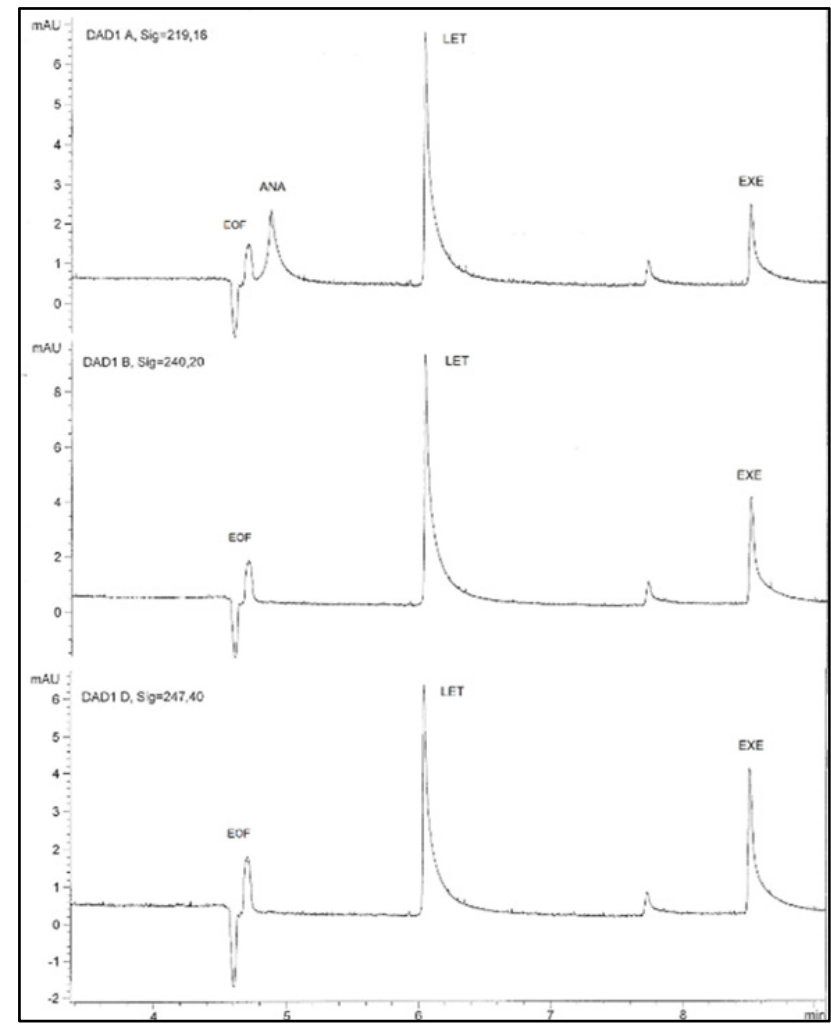

Figure 1. Separation of ANA, LET, and EXE by CZE (working conditions: BGE 100 $\mathrm{mM}$ sodium tetraborate $+5 \mathrm{mMCM}-\beta-C D$, applied voltage: $25 \mathrm{kV}$, injection pressure: $20 \mathrm{mbar} / 2 \mathrm{~s}$ injection pressure, temperature: $25^{\circ} \mathrm{C}$ ).

Method validation. Our optimized method was validated and validation parameters were calculated. The selected internal standard was ciprofloxacin, a stable fluoroquinolone compound with a good signal in the selected BGE [31].

Specificity. The elaborated method allows the detection of an Als derivative from a mixture by quantitative measurement of a parameter (area of the obtained signal). The three selected Als could be quantified without any interference with other present components.

Linearity and detection limits. The linear regression equations were calculated using six concentration levels and three replicates per concentration. Correlation coefficient was over 0.99 , which demonstrates a very good linearity of the method. LOD and LOQ were calculated based on the standard deviation of the response and the slope; the residual standard 
deviation of a regression line or the standard deviation of $y$-intercepts of regression lines was used as the standard deviation in accordance with the International Conference on Harmonization (ICH) criteria (Table 3)[32].

Precision. The precision of the method was investigated in repeatability and intermediate precision terms for migration times and peak areas of the three Als compounds in accordance with ICH criteria [32]. The measurement was performed by six replicate injections of three different concentrations, three consecutive days for all Als. The results, expressed as RSD values, indicate a good precision (Table 4).

Table 3. Linearity - statistical parameters $(T=$ migration time, $A=$ area).

\begin{tabular}{|lclccc|}
\hline Als & $\begin{array}{c}\text { Concentration } \\
\text { domain } \\
\left(\mu \mathrm{g} \cdot \mathrm{mL}^{-1}\right)\end{array}$ & Regression equation & $\begin{array}{c}\text { Correlation } \\
\text { coefficient }\end{array}$ & $\begin{array}{c}\text { LOD } \\
\left(\mu \mathrm{g} \cdot \mathrm{mL}^{-1}\right)\end{array}$ & $\begin{array}{c}\mathrm{LOQ} \\
\left(\mu \mathrm{g} \cdot \mathrm{mL}^{-1}\right)\end{array}$ \\
\hline ANA & $187.5-625$ & $\mathrm{y}=0.0438 \mathrm{x}-3.3156$ & 0.9908 & 51.92 & 173.08 \\
\hline LET & $62.5-500$ & $\mathrm{y}=0.1576 \mathrm{x}-3.5290$ & 0.9936 & 43.40 & 144.67 \\
\hline EXE & $187.5-625$ & $\mathrm{y}=0.0820 \mathrm{x}-4.7439$ & 0.9948 & 42.54 & 141.82 \\
\hline Internal standard CIP & & & & $\mathbf{T}$ & $\mathbf{A}$ \\
\cline { 2 - 6 } $187.5 \mu \mathrm{g} \cdot \mathrm{mL}^{-1}$ & & Average & 7.32 & 23.43 \\
$(\mathrm{n}=18)$ & & $S D$ & 0.314 & 2.47 \\
& & $R S D \%$ & 4.280 & 10.55 \\
\hline
\end{tabular}

Table 4. Intra-day and inter-day precision of CZE method ( $T=$ migration time, $A=$ area).

\begin{tabular}{|l|c|c|c|c|c|c|c|}
\hline Als & $\begin{array}{c}\text { Concentration } \\
\left(\boldsymbol{\mu g} \cdot \mathbf{m l}^{-1} \text { ) }\right.\end{array}$ & \multicolumn{3}{|c|}{$\begin{array}{c}\text { Intra-day precision (RSD\%) } \\
\mathbf{n = 6} \mathbf{~}\end{array}$} & \multicolumn{2}{|c|}{$\begin{array}{c}\text { Inter-day precision (RSD\%) } \\
\mathbf{n = 1 8} \text { Days 3 }\end{array}$} \\
\hline & & $\mathbf{T}$ & $\mathbf{A}$ & & $\mathbf{T}$ & $\mathbf{A}$ & \\
\hline & $\mathbf{6 2 5}$ & 0.493 & 6.183 & & 1.661 & 11.430 & \\
\hline ANA & $\mathbf{5 0 0}$ & 0.247 & 9.174 & & 2.167 & 7.612 & \\
\hline & $\mathbf{3 1 2 . 5}$ & 0.176 & 10.012 & & 1.766 & 11.824 & \\
\hline & $\mathbf{5 0 0}$ & 0.552 & 3.443 & & 0.812 & 14.238 & \\
\hline LET & $\mathbf{3 7 5}$ & 0.243 & 8.969 & & 0.216 & 7.080 & \\
\hline & $\mathbf{1 8 7 . 5}$ & 0.220 & 0.199 & & 0.777 & 13.179 & \\
\hline & $\mathbf{6 2 5}$ & 0.697 & 5.638 & & 4.714 & 14.607 & \\
\hline EXE & $\mathbf{5 0 0}$ & 0.195 & 8.610 & & 4.574 & 8.574 & \\
\hline & $\mathbf{3 1 2 . 5}$ & 0.338 & 4.290 & & 4.457 & 10.700 & \\
\hline
\end{tabular}

Application to biological samples. In order to verify the applicability of our CZE method in determination of Als from biological samples we took in consideration the biotransformation of LET. LET is excreted into urine approximately $70 \%$ of the administered dose as unchanged $(6.0 \pm 3.8 \%)$ or as the glucuronide of the major, pharmacologically inactive metabolite carbinole (CGP44645) (64.2 $\pm 22.7 \%)$ [33,34]. Thus, in a $5 \mathrm{mg}$ administered dose, 0.35 $\mathrm{mg} \pm 0.07 \%$ was recovered in the urine [35]. Analytical performance of our CZE was evaluated on spiked urine from healthy volunteers. 
Specificity. LET could be quantified from spiked urine samples without any interference with other present components (Figure 2).

Linearity and detection limits. The linearity response and detection limits for spiked with LET urine samples are presented in Table 5.

Table 5. Linearity - statistical parameters.

\begin{tabular}{|c|c|c|c|c|c|}
\hline Als & $\begin{array}{c}\text { Conc. domain } \\
\left(\mu \mathrm{g} \cdot \mathrm{mL}^{-1}\right)\end{array}$ & Regression equation & $\begin{array}{c}\text { Correlation } \\
\text { coefficient }\end{array}$ & $\begin{array}{c}\text { LOD } \\
\left(\mu \mathrm{g} \cdot \mathrm{mL}^{-1}\right)\end{array}$ & $\begin{array}{c}\mathrm{LOQ} \\
\left(\mu \mathrm{g} \cdot \mathrm{mL}^{-1}\right)\end{array}$ \\
\hline LET & $50-200$ & $\mathrm{y}=0.3783 \mathrm{x}-4.25$ & 0.9954 & 12.37 & 41.23 \\
\hline
\end{tabular}

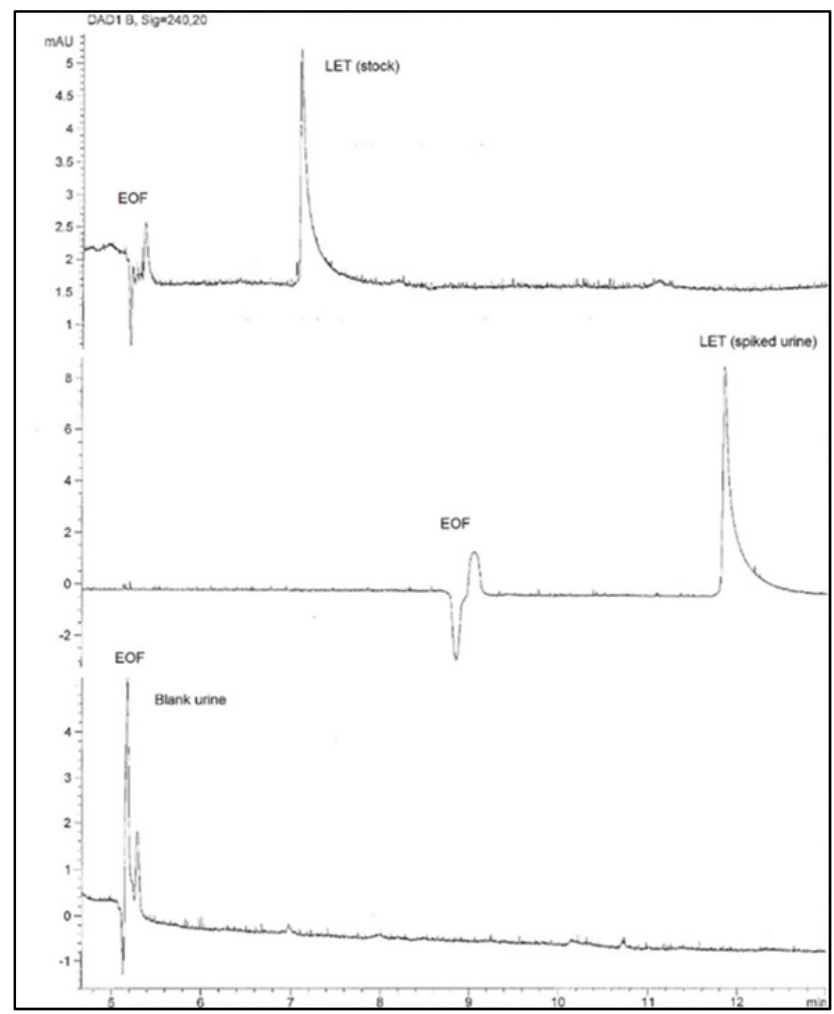

Figure 2.Electrophoregrams of LET from stock solution, spiked urine and blank samples $\left(200 \mathrm{\mu g} \mathrm{mL}^{-1}\right)$ using optimized electrophoretic parameters.

The linear regression equations were calculated using six concentration levels and three replicates per concentration. Correlation was over 0.99 , which demonstrates a very good linearity of the method.

Precision. The precision of the method was investigated in repeatability and intermediate precision terms for migration times and peak areas of LET in spiked urine samples (Table 6). 
Table 6. Intra-day and inter-day precision of CZE method for determination of LET in spiked urine samples ( $\mathrm{T}$ - migration time, A - area).

\begin{tabular}{|l|c|c|c|c|c|c|c|}
\hline Als & $\begin{array}{c}\text { Concentration } \\
\left(\boldsymbol{\mu g} \cdot \mathbf{~ m l}^{-1} \mathbf{)}\right.\end{array}$ & \multicolumn{3}{|c|}{ Intra-day precision (RSD\%) } & \multicolumn{3}{|c|}{$\begin{array}{c}\text { Inter-day precision (RSD\%) } \\
\mathbf{n = 6}\end{array}$} \\
& & $\mathbf{T}$ & $\mathbf{A}$ & & $\mathbf{T}$ & $\mathbf{A}$ & \\
\hline & & 0.489 & 6.701 & & 0.693 & 10.707 & \\
\hline LET & 200 & 0.528 & 5.901 & & 0.667 & 5.309 & \\
\hline & 125 & 0.333 & 5.778 & & 0.474 & 8.646 & \\
\hline
\end{tabular}

Although the results of determination of LET from spiked urine plasma was encouraging, when we tried to quantify the concentration of LET in a concentrated urine clinical sample the method sensibility was too low (Figure 3).

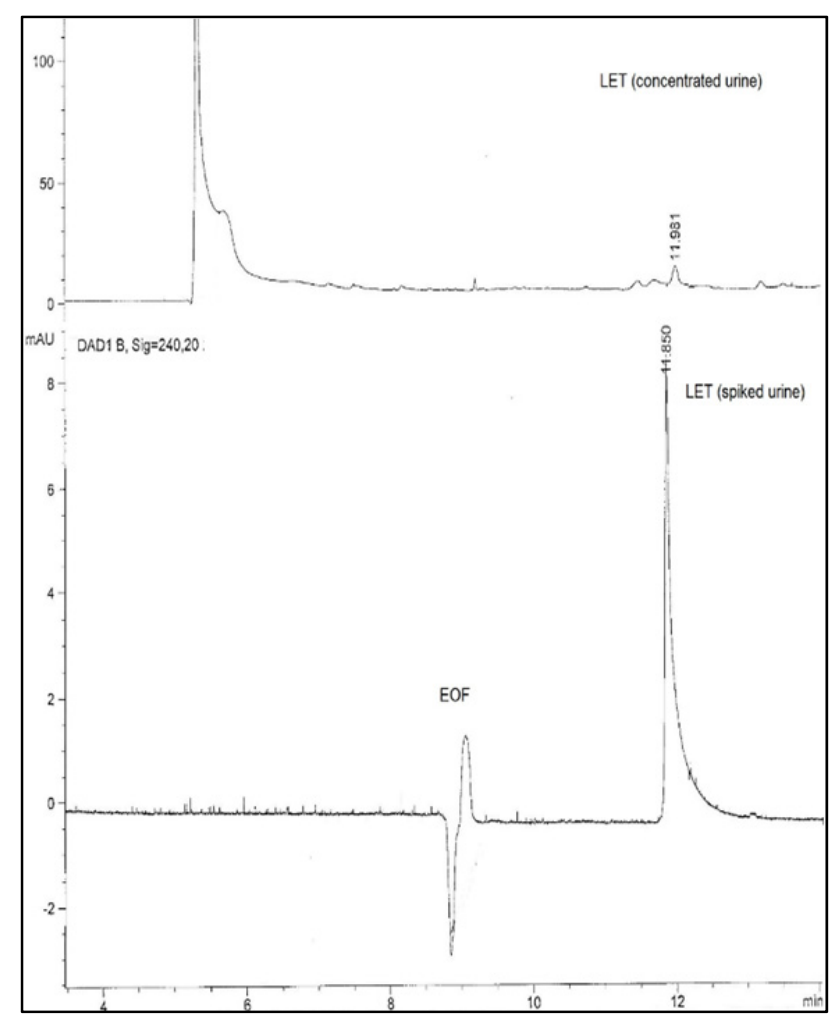

Figure 3. Electrophoregrams of LET from concentrated urine sample and spiked urine samples $\left(200 \mathrm{~g} \mathrm{~mL}^{-1}\right)$ using optimized electrophoretic parameters.

Regarding determination of selected Als our results were not satisfactory as respect to selectivity and migration time. Consequently the method requires further improvements regarding both the electrophoretic method and the sample 
preparation. Also the spiked plasma samples with EXE electrophoregrams present interferences from plasma components (Figure 4).

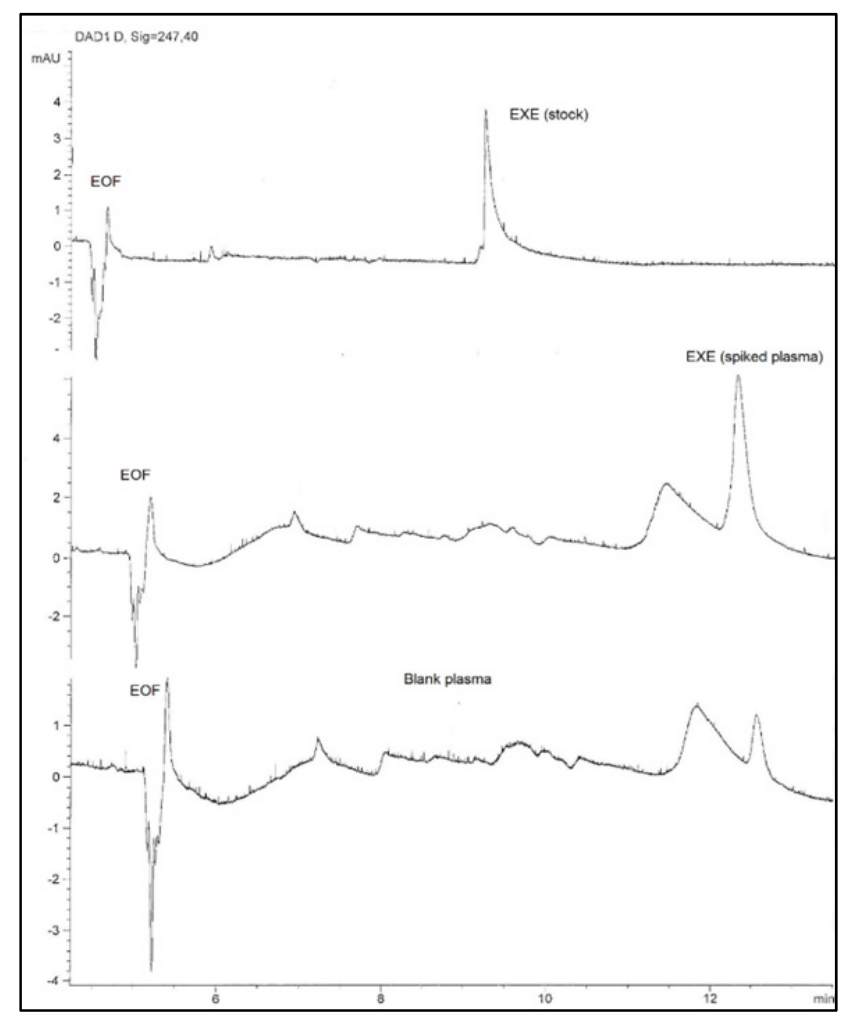

Figure 4. Electrophoregrams of EXE from stock solution, spiked plasma and blank plasma samples $\left(0.67 \mathrm{mg} \mathrm{mL}^{-1}\right)$ using optimized electrophoretic parameters.

Application to Pharmaceutical Formulations. For the determination of ANA and LET from commercial preparations, a total of 20 tablets were weighed and powdered from each commercial product. An equivalent to about $10 \mathrm{mg}$ was weighed accurately and transferred into a $100 \mathrm{ml}$ volumetric flask and $50 \mathrm{ml}$ methanol was added. After ultrasonic vibration for 30 minutes, the mixture was diluted to volume with methanol and then filtrated. A concentration of $100 \mu \mathrm{g} \cdot \mathrm{mL}^{-1}$ of substance was set [36]. For determination of EXE a total of 20 tablets were weighed and powdered. An equivalent to about $400 \mathrm{mg}$ was weighed accurately and transferred into a volumetric flask similar to ANA and LET. Additionally a second dilution was necessary to obtain a concentration of $100 \mu \mathrm{gL}^{-1}$. 
The amount of Als labeled claim and standard deviation were calculated (Table 7).

Table 7. Recovery of ANA, LET and EXE from pharmaceutical formulation (average for three replicates).

\begin{tabular}{lcccc}
\hline $\begin{array}{l}\text { Comercial } \\
\text { product/Producer }\end{array}$ & \multicolumn{4}{l}{ Substance Formulation Amount (mg) Recovery (\%) $\mathbf{\text { SD }}$} \\
\hline Anastrozol/Teva & ANA & Tablets & 1 & $97.64 \pm 4.36$ \\
\hline Letrozol/Teva & LET & Tablets & 2.5 & $99.37 \pm 3.49$ \\
\hline Exemestan/Actavis & EXE & Tablets & 25 & $97.35 \pm 3.89$ \\
\hline
\end{tabular}

Also, our method can be useful in quantifying the three Als from counterfeit drugs.

\section{CONCLUSIONS}

The developed CZE method can be used for separation, identification and quantitative determination for important representatives from Als class. Our validated CZE method is a simple and reliable, using a particular BGE composed of sodium tetraborate and $C M-\beta-C D$ as buffer addtive. With the new validated CZE method we quantified ANA, LET and EXE from pharmaceutical products; the method can find applicability in the analysis of Als counterfeit drugs. Our method also present potential to analyze biological samples. We succeed to quantified LET from spiked urine samples without any special treatment, an encouraging step which demonstrate that the method can be improved for analysis of clinical samples.

\section{EXPERIMENTAL SECTION}

Materials and reagents. The substances and pharmaceutical pruducts were purchased from the following suppliers: ANA, LET and EXE from Sigma Aldrich, borax from Chemical Company, dodecyl sulfate sodium salt from Merck, $\beta$-cyclodextrin ( $\beta$-CD) Biochemica from AppliChem Panreac, 2Hydroxypropyl- $\beta$-cyclodextrin (2-HP- $\beta-C D)$ from AppliChem Panreac, carboxymethyl $\beta$-cyclodextrine (CM- $\beta-C D)$ from Sigma Aldrich, sulfobutyl $\beta$ cyclodextrinefrom (SB- $\beta-C D$ ) from Cyclolab Ltd., ciprofloxacin hydrochloride (CIP) form Ranbaxy Laboratories Limited, Anastrozol $1 \mathrm{mg}$ and Letrozol 2.5 $\mathrm{mg}$ from Teva, Exemestan $25 \mathrm{mg}$ from Actavis. All reagents and solvents were of analytical grade and were obtained from commercial suppliers and used without further purification. The deionized water was prepared with a Milli-Q Direct 8 Millipore system. 
CE system. All CE experiments were conducted in an Agilent $1600 \mathrm{CE}$ system equipped with diode-array detector, while the results were recorded and processed using Chemstation 7.01 software (Agilent). Separations were performed using uncoated fused-silica capillaries of $60 \mathrm{~cm} \times 50 \mu \mathrm{m}$ I.D (effective length $52 \mathrm{~cm}$ ) (Agilent). In all measurements hydrodynamic sample injection was used, by injecting the sample at the anodic end of the capillary, with the detector at the cathodic end.

CZE method. A background electrolyte (BGE) containing $25 \mathrm{mM}$ borax at a $\mathrm{pH}-9.3$ was selected. The detection was carried out in UV at $219 \mathrm{~nm}, 240$ $\mathrm{nm}, 247 \mathrm{~nm}$ and $279 \mathrm{~nm}$, taking into consideration the UV absorption maxima of the studied analytes and internal standard. All experiments were carried out at room temperature. At the beginning of each day the capillary was conditioned with $1 \mathrm{M} \mathrm{NaOH}$ (30 min), deionized water (5 min) and BGE (20 $\mathrm{min}$ ). The capillary was preconditioned before every run with water (1 min) and BGE (2 min). The pH was adjusted using a Terminal 740 (Inolab) $\mathrm{pH}$-meter.

Preparation of stock and standard solutions. The Als stock solutions were prepared daily by dissolving the substance in methanol at $1 \mathrm{mg} \cdot \mathrm{mL}^{-1}$ concentration. They were stored in the refrigerator at $+4^{\circ} \mathrm{C}$, and later diluted to an appropriate concentration.

Urine and plasma sample treatment. Fresh human urine samples and plasma were obtained from different healthy volunteers; a clinical urine sample were provide by a volunteer men ( 45 years old) who has taken 5 $\mathrm{mg}$ of LET then the urine sample was collected after 10 hours. The urine and plasma samples were spiked with LET stock solution, centrifuged (4800 rpm, 10 minutes) and supernatant filtrated ( $0.45 \mu \mathrm{m}$ Whatman filter). The clinical sample was concentrated 16 times with a rotary evaporator at $40^{\circ} \mathrm{C}$ under vacuum, centrifuged $(4800 \mathrm{rpm}, 10$ minutes in a Centurion Scientific Ltd. centrifuge) and supernatant filtrated.

\section{ACKNOWLEDGMENTS}

The research was supported by a project funded through Internal Research Grants by the University of Medicine and Pharmacy of Tîrgu Mures, Romania (grant contract no. 17/23.12.2014). 
DETERMINATION OF LETROZOLE, ANASTROZOLE AND EXEMESTANE BY ...

\section{REFERENCES}

1. A. Trevor, B. Katzung, S. Masters, M. Knuidering-Hall, „Katzung \& Trevor's Pharmacology Examination and Board Review", McGraw-Hill Education, New York, 2012, chapter 40.

2. J. M. Beale Jr., J. H. Block, "Wilson and Gisvold's Textbook of Organic Medicinal and Pharmaceutical Chemistry", Lippincott Williams \& Wilkins, Philadelphia, 2011, chapter 25.

3. J. Berry, Clinical Therapeutics,2005, 27, 167.

4. L. DiGiorgio, H. Sadeghi-Nejad, Translation Andrology and Urology, 2016, 5, 844.

5. S. M. Stephens, A. J. Polotsky, Seminars in Reproductive Medicine,2013, 31, 251.

6. C. E. Vari, B. E. Ösz, A. Miklos, A. Berbecaru-lovan, A. Tero-Vescan, Farmacia, 2016, 64, 813.

7. WADA publishes 2017 Prohibited List https://www.wadaama.org/sites/default/files/resources/files/2016-09-29_-

wada_prohibited list_2017_eng_final.pdf (Accessed 21 April 2017).

8. $\bar{R}$. El Osta, T. Almont, C. Diligent, N. Hubert, P. Eschwège, J. Hubert, Basic and Clinical Andrology,2016; 26, 2.

9. E. Nieschlag, E. Vorona, European Journal of Endocrinology, 2015, 173, R47.

10. S. Budavari, ,The Merck index: an encyclopedia of chemicals, drugs, and biologicals", Whitehouse Station, N.J Merck,1996.

11. K. Wellington, D. M. Faulds, Drugs, 2002, 62, 2483.

12. https://pubchem.ncbi.nlm.nih.gov/compound/2187\#section=Top (Accessed 21 April 2017).

13. J. M. Beale Jr., J. H. Block, "Wilson and Gisvold's Textbook of Organic Medicinal and Pharmaceutical Chemistry", Lippincott Williams \& Wilkins, Philadelphia, 2011, Appendix.

14. P. D. R. Thomson, „Physicians Desk Reference”, Montvale, NJ, 2006.

15. M. Pal, S. Dan, B. Ghosh, A. Das, D. Das, T. K. Pal, Journal of Analytical \& Pharmaceutical Research, 2017, 4, 00093.

16. https://www.accessdata.fda.gov/drugsatfda_docs/nda/99/20753_Aromasin_biopharmr_P1.pdf (Accessed 21 April 2017)

17. J. Rodríguez Flores, J. J. Berzas Nevado, G. Castañeda Peñalvo, M. I. Rodríguez Cáceres, Chromatographia, 2002, 56, 283.

18. J. Rodríguez-Flores, A. M. Contento Salcedo, M. J. Villaseñor Llerena, L. Muñoz Fernández, Electrophoresis, 2008, 29, 81.

19. J. Rodríguez Flores, A. M. Salcedo, M. J. Llerena, L. M. Fernández, Journal of Chromatography A, 2008, 1185, 281.

20. J. Rodríguez-Flores, A. M. Contento Salcedo, L. Muñoz Fernández, Electrophoresis, 2009, 30, 624.

21. S. Orlandini, R. Gotti, S. Furlanetto, Journal of Pharmaceutical and Biomedical Analysis, 2014, 87, 290.

22. K. M. M. Al Azzam, B. Saad, „Determination of Drugs using Capillary Electrophoresis", Lambert Academic Publishing, Saarbrucken, 2012, chapter 1. 
23. G. Hancu, B. Simon, A. Rusu, E. Mircia A. Gyeresi, Advanced Pharmaceutical Bulletin, 2013, 3, 1.

24. T. Loftsson, P. Jarho, M. Másson, T. Järvinen, Expert Opinion on Drug Delivery, 2005, 2, 335.

25. https://www.chemaxon.com/products/marvin/marvinsketch/(Accessed 21 April 2017).

26. P. Schmitt-Kopplin, A. Fekete, Methods in Molecular Biology, 2008, 384, 593.

27. B. Yavuz, C. Sarisözen, I. Vural, E. Bilensoy, M. Sumnu, Journal of Controlled Release, 2010, 20, e83.

28. G. Li, F. Li, L. Deng, X. Fang, H. Zou, K. Xu, T. Li, G. Tan, Steroids, 2013, 78, 1148.

29. M. S. I.Shaikh, N. D. Derle, R. Bhamber, Journal of Applied Pharmaceutical Science, 2012, 02, 34 .

30. M. F. Wempe, C. M. Buchanan, N. L. Buchanan, K. J. Edgar, G. A. Hanley, M. G. Ramsey, J. S. Skotty, P. J. Rice, Journal of Pharmacy and Pharmacology, 2007, 59, 795.

31. A. Rusu, G. Hancu, G. Völgyi, G. Tóth, B. Noszál, Á. Gyéresi, Journal of Chromatographic Science, 2014, 52, 919.

32. http://www.ich.org/fileadmin/Public_Web_Site/ICH_Products/Guidelines/Qualit y/Q2_R1/Step4/Q2_R1_Guideline.pdf (Accessed 21 April 2017).

33. C.U. Pfister, A. Martoni, C. Zamagni, G. Lelli, F. De Braud, C. Souppart, M. Duval, U. Hornberger, Biopharmaceutics \& Drug Disposition, 2001, 22, 191.

34. http://www.bccancer.bc.ca/drug-databasesite/Drug\%20Index/Letrozole_monograph_1April2011.pdf (Accessed 21 April 2017).

35. http://www.accessdata.fda.gov/drugsatfda_docs/nda/97/20726_FEMARA\%20 2.5MG_BIOPHARMR.PDF(Accessed 21 April 2017).

36. S.K. Acharjya, P. Mallick, P. Panda, K.R. Kumar, M.M. Annapurna, Journal of Advanced Pharmaceutical Technology \& Research, 2010, 1, 348. 